\title{
DON KICHOT I INNI. POSTACIE MITYCZNE W PERSPEKTYWIE KOMPARATYSTYCZNEJ, PRACA ZBIOROWA POD REDAKCJĄ LIDII WIŚNIEWSKIEJ, BYDGOSZCZ: WYD. WSG 2012, 380 S.
}

Pierwsza część tytułu recenzowanej publikacji odsyła czytelnika do jednej z najbardziej rozpoznawalnych postaci literackich, stworzonych w Europie nowożytnej, postaci, posiadającej siłę kulturową znoszącą uwarunkowania przestrzenne i czasowe, kształtującej zachowania ludzkie, wyrażającej zbiorowe emocje. Zgodnie z zapowiedzią daną przez redaktorkę tomu - Lidię Wiśniewską, autorzy poszczególnych artykułów koncentrują się na figurach mitycznych (Natura, Bóg), postaciach mitycznych, które biorą swój początek w micie archaicznym lub modernistycznym (Narcyz, Orfeusz, Eros, Psyche) oraz w mitach nowożytnych (Don Kichot i Faust), działających z podobną siłą, jak te wymienione wyżej.

Przedmiotem naszej uwagi będzie część czwarta monografii, zatytułowana Mityczne postacie nowożytnej Europy, w której znalazło się dwanaście artykułów. Dziewięć z nich poświęcono postaci stworzonej przez Miguela de Cervantesa - Don Kichotowi, trzy - bohaterowi dramatu Goethego - Faustowi.

$\mathrm{Na}$ wstępie należy odnotować różnorodność ujęć metodologicznych oraz wielokulturowość badaczy pochodzących z Polski, Ukrainy, Węgier, Słowacji oraz Hiszpanii, co nie pozostaje bez wpływu na wyniki prezentowanych analiz.

Część czwartą otwiera artykuł Lidii Wiśniewskiej zatytułowany „,Don $\mathrm{Ki}$ chote” Cervantesa jako zdesakralizowana synteza mitów Boga i Natury. Zgodnie z nurtem głównego zainteresowania badawczego autorki, sięga ona do klasyfikacji mitów zaproponowanych przez Eliadego i podejmuje próbę usytuowania Don Kichota oraz Sancho Pansy po stronie mitu archaicznego lub modernistycznego. Przedmiotem szczegółowej analizy stają się imiona dwóch wymienionych bohaterów. Przeprowadzona niezwykle sprawnie, wręcz brawurowo, wnikliwa analiza, poparta doskonałą znajomością teorii oraz filozofii mitu, prowadzi autorkę do konkluzji o dwumityczności postaci Cervantesa.

Kolejne dwa artykuły związane są z recepcją postaci Don Kichota w twórczości literackiej oraz w dyskursie filozoficznym.

Pierwszy z nich dotyczy transformacji postaci Don Kichota w twórczości powieściopisarskiej węgierskiego prozaika przełomu XIX i XX wieku - Kálmána Mikszátha. Analizie poddane zostały powieści Oblężenie Bystrzycy oraz Nowa Zriniada. Lászlo Kálmán Nagy odnotował dwa sposoby intertekstualnego odwołania się prozaika węgierskiego do utworu Cervantesa. 
Pierwszym ze sposobów jest trawestacja przygód Don Kichota. Zabieg ten pozwolił pisarzowi ukazać przemiany społeczne na Węgrzech w drugiej połowie XIX wieku - powstanie nowej warstwy społecznej - żyjącej ponad stan zubożałej szlachty, oraz zdemaskować jej wady - bezczynność, marazm, brak aktywności społecznej, pogrążenie w przeszłość, ucieczkę od realnych problemów. Naśladowanie Don Kichota przez głównego bohatera powieści stanowi sposób na ucieczkę od rzeczywistości pozbawionej perspektyw i nowych idei.

Drugim sposobem intertekstualnego dialogu Kálmána Mikszátha z utworem Cervantesa jest aluzja. W fantastyczno-satyrycznej powieści Nowa Zriniada zmartwychwstali rycerze stykają się z cywilizacją końca XIX wieku oraz z bezideowością świata. Nowe czasy, w których brakuje idei, czynią działania rycerzy śmiesznymi. Powieść - zdaniem badacza - stanowi próbę zarysowania satyrycznej panoramy epoki.

Następny artykuł, zatytułowany Don Kichot Emmanuela Lévinasa, autorstwa Ireneusza Szczukowskiego, poświęcony został reinterpretacji powieści Cervantesa w dyskursie filozoficznym francuskiego myśliciela. Lévinasowska interpretacja powieści Cervantesa w wykładzie Don Kichote, zaczarowanie i głód koncentruje się wokół jednego z fragmentów powieści, w którym mowa jest o podstępie cyrulika i proboszcza, próbujących uzdrowić błędnego rycerza, cierpiącego z powodu rozdźwięku między fantazmatem a materialnością zjawisk. Według Lévinasa, sytuacja, w której znalazł się Don Kichot, jest powtórzeniem kartezjańskiej sceny pomieszania prawdy i fałszu, rzeczywistości i snu. Lévinas interpretuje powieść Cervantesa wykorzystując kategorię kartezjańskiego złośliwego demona, który uwiódł Don Kichota. Omówienie wykładu poświęconego Don Kichotowi z uwzględnieniem całokształtu poglądów Lévinasa sytuuje artykuł w szerokim kontekście filozoficznym.

Kolejne artykuły traktują o recepcji postaci Don Kichota w sztukach wizualnych. Pierwsze trzy poświęcone są adaptacjom filmowym. Rozważania badaczy z Hiszpanii, Ukrainy oraz Polski łączy przywołanie jednej z najbardziej znanych radzieckich adaptacji powieści Cervantesa - filmu Grigorija Kozincewa Don Kichot (1957).

Artykuł Jorge Latorre i Ruth Gutierrez Mit Don Kichota w kinie sowieckim i postsowieckim stanowi pogłębione i dojrzałe studium badawcze nad recepcją mitu Don Kichota w Europie Wschodniej. Autorzy uwzględnili szeroki kontekst literacki, historyczny oraz społeczny adaptacji omawianego mitu w krajach byłego bloku wschodniego.

Filmy - Don Kichot Kozincewa, Don Kichot wyzwolony (1987) Wadima Kurczewskiego oraz Don Kichot powraca (1997) Wasilija Liwanowa pozwalaja, ich zdaniem, zrozumieć przekształcenia, jakim został poddany mit w wieku XX.

Autorzy odnotowali zakorzenienie filmowej rosyjskiej wersji Don Kichota w narodowej tradycji literackiej - w utworach Gogola, Turgieniewa, Dostojewskiego, Bułhakowa. Badacze konkluduja, iż film Kozincewa stanowi ,przykład rosyjskiego romantycznego odczytania mitu, pozostającego w zgodzie z mesjanistycznymi 
ideami Dostojewskiego i Turgieniewa, które wpłynęły także na utopijne sowieckie odczytania powieści” (s. 257). Nieprzemijającą wartość rosyjskiej utopii donkiszotyzmu odzwierciedla, zdaniem autorów, również Don Kichot Kurczewskiego. Według Jorge Latorre i Ruth Gutierrez, te dwie nostalgiczne wizje Don Kichota mocno kontrastują z filmową wersją mitu zaproponowaną przez Liwanowa. Film tego reżysera odrywa się do romantycznego donkiszotyzmu rosyjskiego. Jak zauważają autorzy artykułu, w tym Don Kichocie ,idea rosyjskiego romantycznego bohatera także zostaje podjęta, ale tylko po to, by ją podważyć i by pokazać niebezpieczeństwa nowej późnosowieckiej nostalgii, kiedy to społeczeństwo było przerażone możliwością powrotu do komunizmu" (s. 261).

Punkt wyjścia do rozważań nad postaciami Don Kichota i Sancho Pansy dla autora kolejnego artykułu - Oleksandra Pronkevicha, stanowi pojęcie „kodu somatycznego", tj. zbioru cech kanonicznych postaci Don Kichota i Sancho Pansy, które w sposób znaczący wpłynęły na ich przedstawienie w sztukach wizualnych. Pronkevich zauważa, że „kod somatyczny” postaci Don Kichota zbudowany jest w oparciu o opozycje typu: wysoki/niski, gruby/chudy, arystokratyczny/ plebejski i inne.

Wyobrażenia o wyglądzie Don Kichota i Sancho Pansy ostatecznie zostają utrwalone w sztuce filmowej XX wieku. Część zasadnicza artykułu poświęcona została zatem interpretacji form cielesności Don Kichota w filmach Kozincewa, Kurczewskiego i Liwanowa.

Film Grigirija Kozincewa stał się również przedmiotem badań Mariusza Guzka, który wyeksponował intencje ideologiczne reżysera, typowe, jego zdaniem, dla adaptacji klasyki literatury obcej przez Kozincewa. Jak zauważa Guzek, reżyser zdefiniował świat sztuki poprzez świat doświadczany przez niego samego, co poskutkowało przypisaniem ekranowemu tekstowi pozaliterackich znaczeń. Dlatego Kozincew eksploatuje w swoim filmie te wątki powieści Cervantesa, które mogły być bliskie i łatwe do odczytania dla rodzimego adresata, żyjącego w imperialnym, zbiurokratyzowanym kraju, bezdusznie i instrumentalnie traktującym swoich obywateli.

Dzięki indywidualnemu podejściu autorów ostatnich trzech artykułów do prezentowanego materiału, udało im się stworzyć w omawianym tomie spójną i pogłębioną interpretację filmu Kozincewa.

Dwa ostatnie artykuły poświęcone bohaterowi powieści Cervantesa przybliżają czytelnikowi recepcję postaci błędnego rycerza w sztukach plastycznych. Przeprowadzone przez badaczy analizy oraz płynące $\mathrm{z}$ nich wnioski w sposób niezwykle naturalny korespondują z poprzedzającym je materiałem, szczególnie w zakresie badań nad „kodem somatycznym” postaci.

Jana Migasova przyjrzała się malarskiej interpretacji postaci Don Kichota w twórczości słowackiego artysty - Cypriana Majernika, autora cyklu ponad 10 prac poświęconych tej postaci. Do cyklu zaliczane są nie tylko jego obrazy olejne, lecz także rysunki i litografie. Interesującym okazuje się fakt, że artysta 
na wszystkich pracach przedstawił jeden z wielu motywów historii o błędnym rycerzu - motyw jego ucieczki, a wizerunek Don Kichota stworzony został w oparciu o opozycję takich pojęć jak: rzeczywistość i iluzja, codzienność i marzenie, romantyczne porywy i prawda Historii. Badaczka eksponuje również symboliczny charakter prac Majernika, zarówno w zakresie ich struktury, jaki i tematyki. Analiza i interpretacja cyklu pozwala autorce poczynić spostrzeżenia o charakterze uogólniającym, odnoszącym się do całokształtu twórczości Majernika oraz tendencji w malarstwie omawianego okresu, tj. lat 30. i 40. XX wieku.

Z kolei Joanna Bielska-Krawczyk poddała analizie malarskie wizerunki Don Kichota ze zbiorów Muzeum Okręgowego w Toruniu. Zdaniem autorki, zainteresowanie postacią błędnego rycerza w sztukach pięknych wynika z wyjątkowości jego wyglądu. Jak podkreśla Bielska-Krawczyk, charakterystyczne emploi Don Kichota nie przekreśla możliwości tworzenia odmiennych interpretacji tej postaci. Jako przykład badaczka przywołuje trzy prace znajdujące się w Muzeum Okręgowym w Toruniu - obraz Don Kichot i Dulcynea (1956) Wacława Jankowskiego, Portret Don Kichota (1956) Mariana Kratochwila oraz Don Kichot (1961) Tymona Niesiołowskiego.

Omówienie skromnego zbioru prac znajdujących się w toruńskim muzeum pozwoliło autorce zilustrować pewien zakres możliwości interpretowania postaci Don Kichota w malarstwie - jako marzyciela, smętnego myśliciela czy świętego wojownika.

Inna postacią o ogromnej sile oddziaływania stworzoną przez literaturę nowożytną jest Faust. O jej żywotności świadczy liczba utworów, nawiązujących do toposu szalonego naukowca opętanego przez diabła.

Należy odnotować, że autorzy wszystkich zaprezentowanych w omawianym tomie artykułów, odwołują się do mitu Fausta uwiecznionego w tworzywie literackim - w literaturze polskiej, łotewskiej, litewskiej i angielskiej.

Pierwszy z artykułów to próba syntetycznego ujęcia przemian, jakim poddawana była postać Fausta oraz związane z nią motywy w literaturach krajów bałtyckich. Silvestras Gaižiunas dokonując przeglądu sześciu utworów powstałych w latach 1894-1973, wskazuje na główne sposoby transformacji postaci Fausta oraz związanej z nim fabuły w utworach pisarzy litewskich i łotewskich. Autor odnotowuje, że w większości analizowanych przypadków, znana z utworu Goethego fabuła ulega redukcji na rzecz odwołania się pisarzy do pewnej struktury mitologicznej czy nawet archetypicznej. Faust może wyrastać zatem z tego samego archetypu co Prometeusz czy Manfred i być rozpoznawalny również wtedy, gdy przybiera nowe imię.

Literatury litewską i łotewską w zakresie opracowania postaci Fausta cechuje, zdaniem autora artykułu, poszukiwanie mitycznych wzorców, a także rodzimego prototypu bohatera poprzez odwołanie się do tradycji folklorystycznej. Ponadto daje się zauważyć tendencja do polemizowania z przedstawieniem postaci przez Goethego, szczególnie w zakresie egoistycznej postawy bohatera.

Tendencją dominującą w wieku XX staje się demitologizacja bohatera, trawestacja przygód Fausta, odwołanie się do tradycji powieści łotrzykowskiej, 
uaktualnienie historii poprzez wprowadzenie wydarzeń historycznych lub kolorytu narodowego. Wszystko to, zdaniem badacza, stanowi świadectwo uniwersalności postaci stworzonej przez niemieckiego dramaturga.

Zadaniem Agnieszki Kocot-Wierskiej było prześledzenie nowych wcieleń Fausta, wyłamujących się, jej zdaniem, z zakorzenionych w literaturze ujęć. Przykład nowego przedstawienia Fausta stanowią dla autorki dwa dość odległe kulturowo, czasowo oraz gatunkowo utwory - Sonata Belzebuba (1925) Stanisława Witkiewicza i Księga Fausta (1979) Dennisa Enrighta. Kocot-Wierska podejmuje próbę przekonania czytelnika o ich oryginalności względem utworu Goethego, wskazując na takie cechy, jak deheroizacja postaci czy ironiczne lub groteskowe ujęcie jej losów.

Już na pierwszy rzut oka widać, że wybrane do analizy utwory więcej dzieli (forma gatunkowa: dramat Witkacego i poezja Enrighta, czas powstania utworów nierozerwalnie związany z dominującą tradycją literacką, typy bohaterów: naukowiec i artysta), niż łączy. Wydaje się, że to właśnie odmienny charakter obydwu utworów nie pozwolił autorce dokonać spójnej analizy oraz wyciągnąć wniosków. Artykuł został całkowicie pozbawiony tego elementu strukturalnego.

Monika Ładoń - autorka ostatniego artykułu z omawianej grupy - podjęła temat inspiracji faustycznych w Stawie $i$ chwale Jarosława Iwaszkiewicza. Bohaterem powieści jest umierający na gruźlicę gardła kompozytor - Edgar Szyller, który na łożu śmierci sięga po dzieło Goethego. Nieuchronność śmierci pozwala mu spojrzeć na Fausta na nowo. Lektura wybranych fragmentów prowadzi artystę do przewartościowania takich pojęć, jak: nieśmiertelność twórcza, artystyczny odbiór świata, zamierające kompetencje, wiara w sztukę, życie uwewnętrznione. Jak zauważa badaczka, lektura Fausta Goethego w nowych okolicznościach życiowych prowadzi bohatera do gorzkiego rozrachunku z dotychczasowym życiem.

Zamieszczone w omawianym rozdziale artykuły poświadczają ikoniczność takich postaci literackich, jak Don Kichot i Faust, ich zdolność do wyrażania aktualnych dla różnych kultur treści, potencjał znaczeniowy i interpretacyjny oraz niezmienną po dzień dzisiejszy siłę oddziaływania.

$\mathrm{Z}$ uwagi na różnorodne ujęcia badawcze oraz bogaty materiał egzemplifikacyjny prezentowana monografia może stać się cennym źródłem wiedzy dla kulturoznawców, literaturoznawców oraz antropologów.

\section{Aleksandra Szymańska}

Uniwersytet Łódzki Wydział Filologiczny

Instytut Rusycystyki

Zakład Literatury i Kultury Rosyjskiej 90-236 Łódź

ul. Pomorska 171/173 aleksandra.shimanska@yandex.ru 